\title{
GASTROENTERITĂ ACUTĂ CU CLOSTRIDIUM DIFFICILE LA UN COPIL MIC CU INTOLERANȚĂ EREDITARĂ LA LACTOZĂ
}

\author{
Maria Oana Mărginean', Raluca Damian², Andreea Dincă³, \\ Cristina Oana Mărginean ${ }^{1,3}$, Lorena Elena Meliț ${ }^{1,3}$ \\ ${ }^{1}$ Universitatea de Medicină şi Farmacie, Târgu-Mureş \\ ${ }^{2}$ Clinica de Neonatologie I, Târgu-Mureş \\ ${ }^{3}$ Clinica de Pediatrie I, Târgu-Mureş
}

\begin{abstract}
REZUMAT
Gastreoenterita acută cu Clostridium difficile este puțin studiată în literatura de specialitate datorită incidentei scăzute la această vârstă, cu morbiditate şi mortalitate crescute. Prezentăm cazul unei paciente în vârstă de 1 an şi 10 luni, diagnosticată cu intoleranță ereditară la lactoză în perioada neonatală, internată în Clinica de Pediatrie I, Târgu-Mureş, pentru vărsături, inapetență, scaune de consistență modificată, urât mirositoare, cu semne de infectie bacteriană în analizele de laborator şi evoluție lent favorabilă sub tratament cu cefalosporină. Pacienta se reinternează după o zi de la externare cu reapariția inapetenței şi a scaunelor urât mirositoare, cu evoluție nefavorabilă la introducerea unei cefalosporine de generația 3, astfel că se ridică suspiciunea de infecție cu Clostridium difficile, confirmată prin evidențierea toxinelor din materiile fecale, cu evoluție favorabilă o dată cu introducerea tratamentului pentru germeni anaerobi. Particularitatea cazului constă în apariția unei gastroenterite cu Clostridium difficile la un copil mic (1 an şi 10 luni), cunoscut cu retard în dezvoltarea neuropsihomotorie şi de limbaj, episoade repetate de hipoglicemie, cu intoleranță ereditară la lactoză, care a reprezentat o provocare în stabilirea diagnosticului.
\end{abstract}

Cuvinte cheie: Clostridium difficile, copil, gastroenterită, intoleranță ereditară la lactoză

\section{INTRODUCERE}

Gastroenterita acută se defineşte ca modificarea consistenței scaunelor asociată sau nu cu creşterea frecvenței scaunelor, în context febril sau nu, cu sau fără vărsături. Boala diareică acută este una dintre cele mai frecvente patologii întâlnite la pacienții de vârstă pediatrică. Etiologia acestei patologii este în majoritatea cazurilor una virală, însă nici etiologiile bacteriană şi parazitară nu sunt rare. Cu toate că infecția cu Clostridium difficile este poate una dintre cele mai frecvente infecții nosocomiale, relativ frecvent întâlnită în patologia adultului, la pacienții de vârstă pediatrică puține informații sunt disponibile în literatura de specialitate referitor la aceasta. Incidența acestei infecții a crescut în ultimele decenii, fapt datorat cel mai probabil folosirii pe scară largă a antibioticelor. Astfel că în ultimele decenii, în rândul copiilor, se descrie în anumite regiuni ale globului o creştere a incidenței anuale de aproximativ 55\% (1). Gastroenterita cu Clostridium difficile poate apărea la orice vârstă, fiind cel mai frec- vent o bacterie de tip nosocomial, deşi achiziția comunitară a acestei bacterii nu este exclusă. În majoritatea cazurilor aceasta se grevează însă în prezența unui teren favorabil. Astfel, printre cei mai frecvenți factori de risc întâlniți la pacienții de vârstă pediatrică sunt: comorbidităţi asociate, folosirea antibioterapiei, administrarea de inhibitori de pompă protonică, ventilația mecanică invazivă, alimentaţia pe sondă nazo-gastrică şi imunosupresia (2). Diagnosticul acestei infecții se stabileşte prin detectarea toxinelor $\mathrm{A} / \mathrm{B}$ din materiile fecale sau în cazuri mai rare în care tabloul clinic sugerează prezența acestei bacterii, cu rezultate discordante în ceea ce priveşte detectarea toxinelor, se poate utiliza şi metoda genetică polymerase-chain reaction (PCR) (3). Tratamentul include agenți cu spectru anaerob, cum ar fi Metronidazolul sau Vancomicina în cazul copiilor. Complicațiile acestei infecții bacteriene sunt foarte severe în majoritatea cazurilor, ducând la creşterea morbidităţii şi mortalității în rândul populației generale, fiind asociată în cazul 
copiilor cu un risc de 6 ori mai crescut de deces intraspitalicesc (4).

\section{PREZENTARE DE CAZ}

Prezentăm cazul unui copil mic, de sex feminin, în vârstă de 1 an şi 10 luni, cunoscută de la vârsta de 3 săptămâni cu intoleranţă ereditară la lactoză, care s-a internat în Clinica de Pediatrie I, Târgu-Mureş, cu vărsături, inapetență, rinoree seroasă şi scaune semiconsistente, urât mirositoare. Din antecedentele heredo-colaterale am reținut că mama este diagnosticată cu intoleranță la lactoză. Antecedentele personale fiziologice au relevat că este al doilea copil, provine dintr-o sarcină patologică (la 19-20 de săptămâni gestaționale a prezentat hidrotorace drept resorbit spontan, amniocenteză negativă), născută la termen, prin operație cezariană, având greutatea la naştere $3.830 \mathrm{~g}$ şi APGAR 8/1 minut şi 9/5 minute, alimentată cu lapte praf fără lactoză de la vârsta de 3 săptămâni. Antecedentele personale patologice au evidențiat sepsis neonatal, intoleranță ereditară la lactoză, retard în dezvoltarea neuro-psihomotorie şi de limbaj. Menționăm, de asemenea, că în primele 6 luni de viață, pacienta a prezentat multiple episoade de hipoglicemie, glicemia fiind foarte dificil de menținut în limite normale până în momentul diversificării. Debutul bolii actuale a fost în urmă cu aproximativ 6 zile, anterior internării, cu vărsături, inapetență, rinoree seroasă şi scaune semiconsistente, motiv pentru care mama s-a prezentat cu ea la medicul de familie, care a recomandat tratament antibiotic şi simptomatic, însă cu evoluție nefavorabilă, internându-se astfel în clinica noastră pentru investigații şi tratament de specialitate.

Examenul obiectiv la internare a pus în evidență următoarele elemente patologice: stare generală uşor influenţată, tegumente uscate, turgor cutanat diminuat, faringe discret hiperemic, rinoree seroasă, abdomen discret dureros difuz la palpare, tranzit intestinal prezent, scaune semiconsistente, fără semne de iritație meningiană, retard în dezvoltarea neuro-psihomotorie şi de limbaj, G: $11,5 \mathrm{~kg}$. Hemoleucograma a pus în evidență un număr uşor crescut al leucocitelor (Leu $13640 / \mu \mathrm{L}$ ) cu neutrofilie (Neu 60,4\%) cu reactanți de fază acută negativi şi o glicemie de 53,4 mg/dL. Am efectuat, de asemenea, coprocultură, examen coproparazitologic şi Rotavirus din materiile fecale, însă toate au fost negative. Astfel, am iniţiat tratament simptomatic cu Metoclopramid, Controloc, Debridat şi Smecta, însă în a doua zi după internare a dezvoltat febră $\left(39^{\circ} \mathrm{C}\right)$ şi creşterea frecvenței scaunelor diareice, urât mirositoare, cu creşterea reactanților de fază acută (PCR 21,91 mg/L), motive pentru care am decis să introducem antibiotic (Axetine). Ecografia abdominală a pus în evidență meteorism abdominal. Evoluția a fost favorabilă sub tratamentul administrat, cu remiterea scaunelor şi a febrei, însă cu menținerea apetitului capricios. După aproximativ 5 zile de la internare, pacienta s-a externat în stare generală relativ bună, fără a prezenta vărsături sau scaune diareice, cu recomandările de a continua tratamentul antibiotic la domiciliu încă 2 zile asociat cu probiotice. La aproximativ 24 de ore de la externare, mama s-a prezentat din nou cu ea deoarece inapetența se accentuează, refuzând să consume per oral, astfel că se reinternează în clinica noastră. După internare, asociază din nou scaune semiconsistente, urât mirositoare, motiv pentru care am decis să schimbăm antibioticul introducând o cefalosporină de generație 3 (Ceftamil). Analizele de laborator au evidențiat leucocitoză (Leu 14.970/ $\mu \mathrm{L})$ cu neutrofilie (Neu $8.700 / \mu \mathrm{L}$ ) şi reactanţi de fază acută pozitivi (PCR 24,3 mg/L). În ziua internării am recoltat din nou coprocultură şi am efectuat, de asemenea, test Rotavirus din materiile fecale, însă rezultatul a fost negativ. După aproximativ 3 zile de la internare, scaunele au continuat să fie semiconsistente, urât mirositoare şi cu mucus asociat, astfel că am ridicat suspiciunea de infecție cu Clostridium difficile confirmată prin identificarea toxinelor din materiile fecale. Astfel, am introdus tratament cu Metronidazol 3x80 mg/zi per oral, timp de 5 zile, cu evoluție favorabilă. Menționăm, de asemenea, că managementul dietetic a reprezentat un aspect particular în acest caz datorită intoleranței ereditare la lactoză şi a antecedentelor de hipoglicemii repetate, astfel că pe parcursul bolii, pacienta a necesitat suplimentare cu glucoză intravenos cu monitorizarea frecventă a glicemiei, înainte de fiecare masă şi în caz de simptomatologie clinică sugestivă. O dată cu redobândirea apetitului alimentar şi a normalizării scaunelor, perfuzia cu glucoză a fost oprită, însă am continuat să monitorizăm glicemia pe parcursul spitalizării. Recomandările la externare referitoare la dietă au fost de a evita alimentele dulci concentrate, de a utiliza pe cât posibil alimente bogate în carbohidrați, cu eliberare treptată a glucozei în vederea menținerii glicemiei la valori constante (orez, carne, cartofi, cereale etc.), fără fructe şi legume proaspete timp de aproximativ o lună, cu monitorizarea glicemiei cel puțin o dată pe săptămână. Particularitatea cazului constă în apariţia unei enterocolite cu Clostridium difficile la un copil mic (1 an şi 10 luni), cunoscut cu retard în dezvoltarea neuro-psihomotorie şi de limbaj, episoade repetate de hipoglicemie, cu intoleranță ere- 
ditară la lactoză, care a reprezentat o provocare în stabilirea diagnosticului.

\section{DISCUȚII}

Incidența infecției cu Clostridium difficile a crescut dramatic în ultimele decenii conform mai multor studii efectuate în Statele Unite ale Americii (5-7). Acest fapt se pare că se datorează în principal utilizării pe scară larga a antibioterapiei. În ceea ce priveşte clasa de antibiotice asociate cel mai frecvent cu infecția cu Clostridium difficile, Fisher subliniază în studiul său efectuat pe 8.268 de copii diagnosticați cu leucemie acută limfoblastică următorul fapt: beta-lactamicele sunt pe primul loc, pe când utilizarea de cefepime sau ceftazidime sunt independente de această infecție (8). În cazul pacientei noastre, antibioticul utilizat a fost cefuroxime (Axetine) şi ulterior ceftamil, care nici unul nu fac parte din clasa beta-lactamicelor, motiv pentru care tindem să credem că pacienta era purtătoare asimptomatică a aceste bacterii anaerobe, fapt descris şi de literatura de specialitate (9). Cu toate că infecția cu Clostridium difficile era cunoscută tipic ca fiind o infecție nosocomială, se pare că incidența cazurilor care au dobândit infecția în comunitate e în creștere, astfel că într-un studiu efectuat pe 684 de cazuri cu infecție cu Clostridium difficile, $304 \mathrm{au}$ fost comunitare, 338 au fost nosocomiale, iar 42 nedeterminate (10). În vestul României, incidența pe spital este de aproximativ 20,47/15,7 la 1.000 de pacienți externați în 2013/2014, cu 0,62\% la vârsta de sub 20 de ani (11). În ceea ce priveşte factorii de risc la populația studiată, se pare că peste jumătate dintre pacienții care au dezvoltat această infecție au primit antibioterapie, şi spre deosebire de studiul menționat anterior, majoritatea dintre ei au primit cefalosporine şi fluorochinolone $(31,03 \%$, respectiv 28,96\%) (11). Factorii de risc predictibili pentru evoluție nefavorabilă identificați în acest studiu au fost: vârsta, leucocitoza peste 16.000 de celule $/ \mu \mathrm{L}$, hipoalbuminemia sub $3,5 \mathrm{~g} / \mathrm{dL}$, febră peste $37,5^{\circ} \mathrm{C}$, boală pulmonară cronică sau patologie moderată/ severă hepatică, chimioterapie, nutriție parenterală, continuarea terapiei antibiotice după debutul diare- ei (alta decât cea pentru Clostridium difficile), numărul de zile de administrare a antibioticului şi numărul de agenți antibacterieni (11). Totuşi, copiii sunt cei care dezvoltă mai des infecții comunitare cu Clostridium difficile decât adulții (12), probabil şi din cauza faptului că ei pot constitui rezevoare ale infecției, fiind purtători asimptomatici. Tratamentul este acelaşi atât la adulți, cât şi la copii, dar pacienții de vârstă pediatrică răspund mai bine la metrdonidazol, similar cazului nostru, pe când adulții răspund mai bine la vancomicină (12). Consecințele gastroenteritei acute cu Clostridium difficile la vârstă pediatrică includ: creşterea duratei de spitalizare, mortalitate crescută, costuri de tratament mai crescute, rate mai crescute de colectomie în comparație cu adulții, precum şi reinternări din cauza recurenței infecției sau a evoluției nefavorabile (12), similar cazului nostru. Tratamentul infecției cu Clostridium difficile constă în metronidazol (de primă intenție) sau vancomicină asociate cu măsuri de rehidratare (12). Referitor la prevenția infecției la copii, aceasta se bazează în principal pe utilizarea atentă a terapiei antibiotice, precum şi pe administrarea de probiotice, care ar putea reduce $\mathrm{cu}$ până la $60 \%$ rata de infecție cu acest germene anaerob (13). Cu toate acestea, un studiu efectuat în Statele Unite a identificat 29.000 de decese în anul 2011 din cauza acestei infecții (14).

\section{CONCLUZII}

Gastroenterita acută cu Clostridium difficile este o boală cu complicații severe la vârsta pediatrică. Caracterul ei tipic nosocomial începe să fie tot mai puțin specific, cu creşterea ratei infecțiilor comunitare, fapt care ar trebui să conştientizeze clinicienii şi să îi determine să fie mai responsabili în ceea ce priveşte recomandarea antibioterapiei în ambulator. Creşterea alarmantă a incidenței infecției cu Clostridium difficile la copii în ultimele decenii ar trebui să determine medicul specialist pediatru să suspicioneze această infecție în vederea stabilirii cât mai precoce a diagnosticului şi a administrării terapiei corespunzătoare pentru a preveni apariția complicațiilor. 